\title{
The -174GG Interleukin-6 Genotype Is Protective From Retinopathy and Nephropathy in Juvenile Onset Type 1 Diabetes Mellitus
}

\author{
JOLANTA MYŚLIWSKA, KATARZYNA ZORENA, MAŁGORZATA MYŚLIWIEC, EWA MALINOWSKA, \\ KRYSTYNA RACZYŃSKA, AND ANNA BALCERSKA
}

\begin{abstract}
Department of Immunology [J.M., K.Z., E.M.], Medical University of Gdańsk, Dębinki, 80-210 Gdańsk, Poland; Academic Clinic of Paediatrics, Haematology, Oncology and Endocrinology [M.M., A.B.] and Academic Clinic of Ophthalmology [K.R.], Medical University of Gdańsk, Dębinki, 80-952 Gdańsk, Poland
\end{abstract}

\begin{abstract}
The aim of our study was to determine an association between the $-174 \mathrm{G}>\mathrm{C}$ IL- 6 polymorphism (rs1800795) and occurrence of retinopathy and nephropathy in type 1 diabetes mellitus (T1DM) patients. Two hundred ten children/adolescents with longstanding T1DM (16.5 $\pm 3.8 \mathrm{y}$; with diabetes duration of $8.4 \pm 3.0 \mathrm{y})$ were enrolled into the study. A group of 170 healthy young (16.9 \pm 5.2 y) sex-matched volunteers was qualified as the control. The IL-6 polymorphism was genotyped with the PCR-RFLP method. Serum and urine IL- 6 concentrations were measured by the ultra-sensitive ELISA tests. The $-174 \mathrm{GG}$ genotype was under represented in the diabetic patients compared with the controls. Patients with this genotype were free from nephropathy and retinopathy. The group of $-174 \mathrm{GG}$ carriers was characterized by the highest urine IL- 6 concentrations in relation to other genotypes. In the multivariate logistic regression analysis adjusted for age, duration of the disease, age of disease onset, HbA1c, and albumin excretion rate, the -174GG genotype was the only independent variable that significantly decreased the risk of jointly analyzed retinopathy and nephropathy $[\mathrm{OR}=0.65 ; 95 \%$ $\mathrm{CI}=0.52-0.82 ; p=0.0003]$. We propose that the $-174 \mathrm{GG}$ patients are protected from late diabetic complications by different IL-6 dependent mechanisms. (Pediatr Res 66: 341-345, 2009)
\end{abstract}

$\mathrm{L}$ ow-grade inflammation underlies the course of long-term type 1 diabetes mellitus (T1DM). Diabetic retinopathy and nephropathy entail an exacerbation of inflammatory conditions with the serum IL-6 level correlating with the occurrence of microvascular complications (1). The amount of IL-6 production is dependent on transcriptional regulation of this cytokine. The polymorphic region $-174 \mathrm{G}>\mathrm{C}$ of IL-6 encoding gene is implicated in transcription of this cytokine. The $\mathrm{G}>\mathrm{C}$ nucleotide substitution creates a potential binding site for the transcription factor NF-1 and the $-174 \mathrm{G}$ allele, in a reporter gene assay in vitro was found to have twice as much promoter strength as the $\mathrm{C}$ allele (2). In line with the molecular results, the clinical data place the $-174 \mathrm{GG}$ genotype as the most proinflammatory one within the rs 1800795 polymorphism. High IL-6 ex vivo production was documented in the -174GG healthy individuals compared with other genotype carriers (3). The healthy $-174 \mathrm{G}$ allele carriers turned out to be high IL-6 producers after vaccination with Salmonella typhii

Received January 5, 2009; accepted May 7, 2009

Correspondence: Katarzyna Zorena, PhD, Department of Immunology, Medical University of Gdańsk, Dębinki 1, 80-210 Gdańsk, Poland; e-mail: kzorena@amg.gda.pl

Supported by the MNiSW Grant N N407 173034 (to J.M.) and Medical University of Gdańsk Grants ST-28 (to J.M.), ST-8 (to A.B.), and ST-56 (to K.R.) vaccine (4). It was documented that patients with the $-174 \mathrm{GG}$ genotype run a risk of an earlier onset and more serious outcome of cardiovascular and cerebrovascular diseases (5-9). Also, the IL-6 promoter polymorphism seems to have influence on various postoperative short-term (10-12) and longterm complications $(13,14)$ as well as on the frequency and severity of different cardiovascular events $(15,16)$.

Although the presented evidence favors the proinflammatory character of the $-174 \mathrm{GG}$ genotype, some other data may raise doubts about universality of this phenomenon. For example, in the studies of Humphries et al. (17), it was the $-174 \mathrm{C}$ allele carriers that had the increased risk of higher systolic blood pressure and coronary heart disease. In addition, it was the $-174 \mathrm{C}$ allele carriers that produced in vivo the highest amount of IL- 6 and had less favorable outcome of coronary revascularization surgery than the GG homozygotes (18).

The data concerning an association between T1DM and the $-174 \mathrm{G}>\mathrm{C}$ IL-6 polymorphism are inconsistent and mostly limited to the assessment of the disease risk (19-25). In a study on 206 Dutch families with juvenile onset of T1DM, no association between the single rs 1800795 polymorphism and T1DM has been found (20). In a genome-wide association study comprising 7758 cases and 8852 controls, a borderline significance has been reported for the $-174 \mathrm{CC}$ genotype indicating an increased susceptibility to T1DM (21). The three other articles dealing with juvenile onset of T1DM imply that the IL-6 genotypic variants may influence the time of disease onset or modulate the risk of diabetes development (22-24). Moreover, a recently published article has observed a trend toward higher frequency of retinopathy within the $-174 \mathrm{CC}$ genotype in adult diabetes type 1 and type 2 patients (25).

The aim of our study was to determine an association between the $-174 \mathrm{G}>\mathrm{C}$ IL-6 polymorphism (rs1800795) and the occurrence of retinopathy and nephropathy in juvenile onset T1DM patients.

\section{METHODS}

Participants. The study was conducted on a group of 210 children/ adolescents $16.5 \pm 3.8$ y with long-standing T1DM (100 boys, 110 girls), from the Outpatient's Diabetology Clinic at the Medical University of Gdańsk, Poland. The diagnosis of T1DM was carried out in accordance with the American Diabetes Association Criteria (26). Patients with coexisting

Abbreviations: T1DM, type 1 diabetes mellitus 
Table 1. Clinical characteristics of the diabetic patients and healthy group

\begin{tabular}{|c|c|c|c|c|}
\hline & $\begin{array}{l}\text { Patients without complications } \\
\qquad(n=172)\end{array}$ & $\begin{array}{l}\text { Patients with complications } \\
\qquad(n=38)\end{array}$ & $\begin{array}{l}\text { Healthy group } \\
\quad(n=170)\end{array}$ & Statistical significance $(p)$ \\
\hline Gender (f/m) & $86 / 86$ & $20 / 18$ & $80 / 90$ & \\
\hline Age $(y)$ & $16.1 \pm 1.7$ & $18.8 \pm 2.1$ & $16.9 \pm 5.2$ & $\begin{array}{l}0.63^{*} \\
0.008 \dagger\end{array}$ \\
\hline Disease onset & $8.1 \pm 4.5$ & $8.5 \pm 3.5$ & - & $0.03 \dagger$ \\
\hline Duration of the disease $(y)$ & $8.0 \pm 3.0$ & $10.3 \pm 2.8$ & - & $0.0001 \dagger$ \\
\hline $\mathrm{HbA} 1 \mathrm{c} \%$ & $8.0 \pm 1.4$ & $9.18 \pm 2.1$ & - & $0.0001 \dagger$ \\
\hline Albumin excretion rate $(\mathrm{mg} / 24 \mathrm{~h})$ & $16.9 \pm 11.1$ & $40.3 \pm 5.8$ & $3.5 \pm 2.1$ & $\begin{array}{l}0.0001 * \\
0.0001 \dagger\end{array}$ \\
\hline Creatinine in serum $(\mu \mathrm{mol} / \mathrm{L})$ & $0.71 \pm 0.07$ & $0.79 \pm 0.12$ & $0.50 \pm 0.01$ & $\begin{array}{l}0.0001^{*} \\
0.02 \dagger\end{array}$ \\
\hline Systolic blood pressure (mm $\mathrm{Hg}$ ) & $111 \pm 11$ & $118 \pm 12$ & $107 \pm 8$ & $\begin{array}{l}0.0001^{*} \\
0.0005 \dagger\end{array}$ \\
\hline Diastolic blood pressure (mm $\mathrm{Hg}$ ) & $71 \pm 8$ & $75 \pm 11$ & $62 \pm 6$ & $\begin{array}{l}0.0001^{*} \\
0.007 \dagger\end{array}$ \\
\hline
\end{tabular}

* Statistical significance between the whole group of diabetic patients.

$\dagger$ Statistical significance between the patients without and with diabetic complications.

autoimmune diseases as well as with additional chronic and acute diseases were excluded from the study. All the patients were treated with humanized insulin. Retinopathy was defined according to the ETDRS Research Group Ophthalmology criteria (27). In all the examined patients, the C-peptide level was found to be $<0.5 \mathrm{ng} / \mathrm{mL}$. The urinary albumin excretion was expressed as the average of three 24-h collections obtained during 6 mo before enrolment into the study. The cases that, in at least two out of three urine samples, had albumin excretion within the range of $30-299 \mathrm{mg} / 24 \mathrm{~h}$ were classified as microalbuminuria. The urinary albumin excretion was measured by immunoturbidometric assay using Tina-quant (Boehringer Mannheim GmbH, Germany). Urinary creatinine and IL-6 were measured from the same sample of $24 \mathrm{~h}$ urine collection. The glomerular filtration rate (GFR) was estimated by calculation of the creatinine clearance $\left(\mathrm{Cl}_{\mathrm{Cr}}\right)$ from serum creatinine concentration using the Cockroft-Gault formula, which is suitable for children: $\mathrm{Cl}_{\mathrm{Cr}}$ $(\mathrm{mL} / \mathrm{min})=[(140-$ age $) \times$ weight $] /\left(72 X_{\mathrm{SCr}}[\mathrm{mg} / \mathrm{dL}]\right) \times 0.85$ (if girl); $\mathrm{SCr}=$ serum creatinine (28). A group of 170 healthy young age (16.9 \pm $5.2 \mathrm{y}$ ) and sex-matched volunteers was qualified as the control. Informed consent was obtained from parents of all children enrolled in the study. Children older than $16 \mathrm{y}$ also provided consent. The Ethics Committee of the Medical University of Gdańsk approved this study.

Serum IL-6 and urine IL-6 concentrations. These were measured by the ultra-sensitive ELISA test (Quantikine HS IL-6 kit; R\&D Systems, Minneapolis, MN) according to the manufacturer protocol. Minimum detectable concentrations for IL- 6 were determined by the manufacturer as $0.03 \mathrm{pg} / \mathrm{mL}$ in serum and $0.1 \mathrm{pg} / \mathrm{mL}$ in urine.

Genotyping. IL-6 polymorphism was analyzed with the PCR-RFLP according to Fishman et al. (2) using the following primers: 5' AGAAGAACTCAGATGACTGG $3^{\prime}$ and 5' GCTGGGCTCCTGGAGGGG 3'. The PCR products were cut by the restriction enzyme $S f a \mathrm{NI}$ (New England Biolabs) and electrophoresed on $2 \%$ agarose gel, stained with ethidium bromide. DNA samples were first sequenced to establish three IL6 polymorphic variants, as a quality control. Next, DNA samples of the $-174 \mathrm{GG}, \mathrm{GC}$, and CC individuals were routinely added to the examined ones to ensure genotype accuracy.

Statistical analysis. The results were analyzed using the Statistica, Version 7 program (StatSoft, Pl). The Shapiro-Wilk's test was used to evaluate normality of variables. Differences between the groups of normally distributed variables were calculated with the ANOVA or $t$ tests. For comparison of the skew-distributed variables, the nonparametric Kruskal-Wallis ANOVA or Mann Whitney $U$ tests were applied. Nominal variables were analyzed by the $\chi^{2}$ Pearson's $\chi^{2}$ test. The two-tailed probability values were calculated. A multivariate logistic regression analyses was performed to assess the association between nephropathy and retinopathy incidence and all the variables significant for late diabetic complications. Finally, a statistical power analysis was carried out to establish whether the number of patients GG was sufficient to conclude a hypothesis about protective effect of this genotype against diabetic complications. The $\alpha$ level was set at 0.05 .

\section{RESULTS}

Clinical characteristics of the patients and the healthy group are presented in the Table 1 . The genotype distribution was significantly different between the patients and healthy group
Table 2. The $-174 G>C$ genotype distribution in diabetic patients and healthy group

\begin{tabular}{|c|c|c|c|c|}
\hline \multirow{2}{*}{$\begin{array}{l}-174 \mathrm{G}>\mathrm{C} \\
\text { genotypes }\end{array}$} & \multicolumn{2}{|c|}{$\begin{array}{l}\text { Healthy group } \\
\quad(n=170)\end{array}$} & \multicolumn{2}{|c|}{$\begin{array}{l}\text { Patients } \\
(n=210)\end{array}$} \\
\hline & $n$ & $\%$ & $n$ & $\%$ \\
\hline $\mathrm{CC}$ & 51 & 30 & 69 & 33 \\
\hline GC & 68 & 40 & 110 & 52 \\
\hline GG & 51 & 30 & 31 & 15 \\
\hline$\chi^{2}$ Pearson & 0.01 & & & \\
\hline
\end{tabular}

* Statistical significance between the patients and healthy group.

$(p=0.01)$. The $-174 \mathrm{GG}$ genotype was under represented in the group of diabetic patients, with only $15 \%$ having this genotype, in relation to the control group with the $-174 \mathrm{GG}$ participants amounting to $30 \%$ (Table 2).

Among the 210 diabetic children/adolescents, 38 patients had one or two complications. Twenty-one patients had two complications. Nephropathy was diagnosed in 23 and retinopathy in 36 of them. Two patients with nephropathy were free from retinopathy and 15 patients with retinopathy were free from nephropathy. The patients with nephropathy and retinopathy were within the $-174 \mathrm{CC}$ and the GC genotypes, whereas no complications were found within the $-174 \mathrm{GG}$ group. The $-174 \mathrm{G}>\mathrm{C}$ IL-6 genotype distributions within the patients with nephropathy and retinopathy versus those free of both late diabetic complications were significantly different $(p=$ 0.005 and $p=0.01$, respectively). There were no differences in onset of the disease and its duration between patients with different $-174 \mathrm{G}>\mathrm{C}$ variants (Table 3 ).

The serum IL-6 concentrations were about four times higher in the patients than in the healthy group. The $-174 \mathrm{GG}$ patients were characterized by similar IL-6 serum level as the other genotype's groups $(p=0.75)$. Similarly, no genotypedependent differences in serum IL-6 level were found among the healthy group $(p=0.9)$.

The diabetic patients excreted more urine IL-6 than the healthy group. The urinary IL- 6 level in the $-174 \mathrm{GG}$ patients was significantly higher $(p=0.0007)$ in relation to other genotypes. The urine IL- 6 concentration was of similar values in the genotype groups among the healthy children $(p=0.36)$. 
Table 3. The $-174 G>C$ genotype distribution in relation to diabetic complications

\begin{tabular}{|c|c|c|c|c|c|c|c|}
\hline \multirow[b]{2}{*}{$\begin{array}{l}-174 \mathrm{G}>\mathrm{C} \\
\text { genotypes }\end{array}$} & \multirow[b]{2}{*}{$\begin{array}{l}\text { Diabetic patients } \\
\quad(n=210)\end{array}$} & \multirow[b]{2}{*}{ Disease onset } & \multirow[b]{2}{*}{$\begin{array}{c}\text { Duration of the } \\
\text { disease }\end{array}$} & \multicolumn{2}{|c|}{ Nephropathy $n(\%)$ of patients* } & \multicolumn{2}{|c|}{ Retinopathy $n(\%)$ of patients $\dagger$} \\
\hline & & & & $\begin{array}{l}\text { Free of both } \\
\text { complications }\end{array}$ & With nephropathy & $\begin{array}{l}\text { Free of both } \\
\text { complications }\end{array}$ & With retinopathy \\
\hline $\mathrm{CC}$ & 69 & $8.5 \pm 5.6$ & $8.5 \pm 2.7$ & $59(85 \%)$ & $10(15 \%)$ & $57(83 \%)$ & $12(17 \%)$ \\
\hline GC & 110 & $8.1 \pm 3.9$ & $8.4 \pm 3.2$ & $88(88 \%)$ & $13(13 \%)$ & $86(78 \%)$ & $24(22 \%)$ \\
\hline GG & 31 & $8.2 \pm 3.9$ & $8.8 \pm 3.2$ & $31(100 \%)$ & $0(0 \%)$ & $31(100 \%)$ & $0(0 \%)$ \\
\hline$\chi^{2}$ Pearson & & $p=0.774$ & $p=0.754$ & \multicolumn{2}{|c|}{$p=0.005$} & \multicolumn{2}{|c|}{$p=0.01$} \\
\hline
\end{tabular}

* Percent of patients with nephropathy within a given genotype group in relation to the entire genotype group

$\dagger$ Percent of patients with retinopathy within a given genotype group in relation to the entire genotype group.

Table 4. Serum and urinary IL-6 in carriers of the polymorphic $-174 G>C I L-6$ variants

\begin{tabular}{lccccc}
\hline & IL-6 genotype & IL-6 serum $(\mathrm{pg} / \mathrm{mL})$ & $\mathrm{IL}-6$ urine $(\mathrm{pg} / \mathrm{mL})$ & ${\text { GFR }\left(\mathrm{CL}_{\mathrm{Cr}}\right)(\mathrm{mL} / \mathrm{min})}^{\mathrm{uIL}-6 / \mathrm{urine} \mathrm{creatinine}(\mathrm{pg} / \mathrm{mg})}$ \\
\hline Diabetic patients & CC & $1.26 \pm 1.09$ & $1.74 \pm 0.56$ & $102 \pm 31$ & $2.4 \pm 1.2$ \\
& GC & $1.34 \pm 1.20$ & $1.71 \pm 0.81$ & $101 \pm 38$ & $4.3 \pm 2.5$ \\
& GG & $1.32 \pm 1.01$ & $6.47 \pm 2.26$ & $100 \pm 29$ & $7.3 \pm 4.8$ \\
Healthy group & $p$ & $0.75^{*}$ & $0.0007^{*}$ & $0.98 \dagger$ & $-0.04 \dagger$ \\
& GC & $0.39 \pm 0.32$ & $0.54 \pm 0.32$ & - & - \\
Statistical significance & GC & $0.35 \pm 0.23$ & $0.32 \pm 0.07$ & - & - \\
\hline
\end{tabular}

uIL-6, IL-6 in urine.

* Kruskal Wallis ANOVA.

$\dagger$ ANOVA.

Table 5. Patients with and without complications representing polymorphic variants of IL-6

\begin{tabular}{|c|c|c|c|c|c|c|c|}
\hline IL-6 genotype & Age (y) & Disease duration (y) & Disease onset (y) & $\begin{array}{l}\text { Albumin excretion } \\
(\mathrm{mg} / 24 \mathrm{~h})\end{array}$ & HbA1c (\%) & IL-6 serum $(\mathrm{pg} / \mathrm{mL})$ & IL-6 urine $(\mathrm{pg} / \mathrm{mL})$ \\
\hline $\begin{array}{l}\text { With complications } \\
\qquad \mathrm{GC}+\mathrm{CC}(n=38)\end{array}$ & $18.8 \pm 2.1$ & $10.3 \pm 2.8$ & $8.5 \pm 3.5$ & $40.3 \pm 5.8$ & $9.18 \pm 2.1$ & $1.34 \pm 1.40$ & $2.1 \pm 2.2$ \\
\hline $\begin{array}{l}\text { Without complications } \\
\qquad \mathrm{GC}+\mathrm{CC}(n=141)\end{array}$ & $16.0 \pm 1.3$ & $7.9 \pm 3.0$ & $8.1 \pm 4.7$ & $17.3 \pm 11.2$ & $8.0 \pm 1.4$ & $1.44 \pm 1.52$ & $1.5 \pm 1.8$ \\
\hline $\begin{array}{l}\text { Without complications } \\
\text { GG }(n=31)\end{array}$ & $17.0 \pm 3.5$ & $8.8 \pm 3.2$ & $8.2 \pm 3.9$ & $15.6 \pm 11$ & $7.9 \pm 1.6$ & $1.56 \pm 1.47$ & $6.5 \pm 2.2$ \\
\hline \multirow[t]{3}{*}{$p$} & $0.003^{*}$ & 0.000000 & 0.008 & 0.0005 & 0.000000 & 0.6 & 0.2 \\
\hline & $0.07 \dagger$ & 0.000000 & 0.01 & 0.004 & 0.00001 & 0.44 & 0.04 \\
\hline & $0.79 \ddagger$ & 0.85 & 0.56 & 0.83 & 0.71 & 0.59 & 0.000000 \\
\hline
\end{tabular}

* Differences between values of the GC + CC group with complications vs the group GC + CC without complications.

$\dagger$ Differences between values of the GC $+\mathrm{CC}$ group with complications $v s$ the GG group without complications.

\$Differences between values of the groups without complications, i.e. the GG $v s$ the GC + CC group.

The values of GFR were similar for all $-174 \mathrm{G}>\mathrm{C}$ genotypes $(p=0.98)$. The urine IL- 6 concentration standardized to the urinary creatinine level was highest in the $-174 \mathrm{GG}$ and lowest in $-174 \mathrm{CC}$ diabetic patients $(p=0.04)$ (Table 4).

Next, the presence of nephropathy and retinopathy was analyzed with respect to IL-6 polymorphism. It appeared that the $-174 \mathrm{CC}$ and GC patients without complications were younger $(p=0.003)$, had shorter disease duration $(p=$ $0.000000)$, later disease onset $(p=0.008)$, lower albumin excretion $(p=0.0005)$, and lower HbA1c $(p=0.000000)$ level in relation to the $-174 \mathrm{CC}$ and GC patients with complications. However, there were no differences between the concentrations of IL- 6 in serum $(p=0.6)$ and urine $(p=0.2)$. In addition, the $-174 \mathrm{GG}$ complications free group was younger $(p=0.07)$ had shorter disease duration $(p=$ $0.000000)$, later disease onset $(p=0.01)$, lower albumin excretion $(p=0.004)$, and lower HbA1c $(p=0.000000)$ values in relation to the group with complications. The $-174 \mathrm{GG}$ patients did not differ in a significant way from the complications free 174CC and -174GC genotype carriers with respect to majority of clinical parameters. The only difference between the groups was found in the urine IL-6 concentration that was significantly higher in the $-174 \mathrm{GG}$ patients $(p=0.000000)$ (Table 5).

In the multivariate logistic regression analysis adjusted for age, duration of the disease, age of disease onset, HbAlc, albumin excretion rate the presence of $-174 \mathrm{G}$ allele significantly decreased the risk of the jointly analyzed retinopathy and nephropathy $[\mathrm{OR}=0.65 ; 95 \% \mathrm{CI}=0.52-0.82 ; p=$ 0.0003]. The remaining parameters did not affect the risk of diabetic complications. The significance of the $174 \mathrm{G}$ allele was lost when retinopathy and nephropathy were analyzed separately. Moreover, the post hoc power analysis revealed that to guarantee a high statistical power of 0.900 with the $\alpha$ value set at 0.05 the number of $-174 \mathrm{GG}$ complications free patients should be 86 while the patients evaluated in our study amounted only to 31 individuals. The current power of the logistic regression calculations was 0.634 . 


\section{DISCUSSION}

Reduced representation of the IL-6 -174GG genotype found among our patients in comparison to the healthy group points to an association between the $-174 \mathrm{C}$ allele and juvenile diabetes risk.

Such a genotype distribution profile is in agreement with the data of Gillespie et al. (22) who found that the $-174 \mathrm{G}$ allele decreases the risk of diabetes type 1 onset before the age of $10 \mathrm{y}$ in girls. An analogous conclusion is derived from the article of Hermann et al. (23) who found that the $-174 \mathrm{G}$ allele carrier status is associated with a later onset of diabetes type 1 in children. In a complementary article, Jahromi et al. (24) found an enrichment till $69 \%$ of the $-174 \mathrm{G}$ allele in a group of adult T1DM patients compared with normal controls. The results of the cited articles imply that the $-174 \mathrm{GG}$ genotype is protective against an early T1DM onset but this protection may be lost in the later life.

Although we did not replicate an association between the $-174 \mathrm{GG}$ genotype and a later onset of the disease, which was done by Gillespie et al. (22) and Hermann et al. (23), we suggest a protective effect of the $-174 \mathrm{GG}$ genotype against late diabetic complications in juvenile diabetes. However, one has to treat our results with reservation because they lack the sufficient statistical power (value of power 0.634 with $\alpha=$ 0.05 ), and to make them reliable, the number of $-174 \mathrm{GG}$ patients should be increased about three times. Our results complement two other articles. A recently published the first large cross-sectional study has found a trend toward a higher frequency of diabetic retinopathy in type 1 and type 2 diabetic patients with the $-174 \mathrm{CC}$ genotype (25). Moreover, in a genome-wide association study a borderline significance was reported for the $-174 \mathrm{CC}$ genotype to indicate an increased susceptibility to T1DM (21).

How are we to reconcile the most inflammatory character of the $-174 \mathrm{GG}$ genotype with the protection from diabetes and its complications? It follows from the literature $(2,4,10,16)$ that an enhanced IL- 6 response in the $-174 \mathrm{GG}$ genotype patients may have beneficial effects.

For example, elevated IL-6 serum level has been found to be associated with higher fasting and postload insulin level in healthy human population, implying that IL-6 may encourage insulin secretion $(29,30)$. In line with this suggestion, it was revealed that IL-6 might directly stimulate insulin secretion from rat pancreatic islets (31) as well as from cultures of these cells in vitro (32). Thus, if such conditions really exist in -174GG homozygotes at prediabetes stage, insulin secretion in them may be relatively high until clinical manifestation of the disease.

IL-6 may also delay pancreatic beta cell damage by its anti-inflammatory effect, which contributes to amelioration of the insulitis (33-35). Induction of the circulating IL-1 receptor antagonist and the soluble TNF $\alpha$ p 55 receptor demonstrate the well-known anti-inflammatory effects of IL-6 (36). The prophylactic and therapeutic effect of the soluble TNF- $\alpha$ receptor type I, as TNF- $\alpha$ antagonist, against diabetic insulitis has already been documented in female nonobese diabetic (NOD) mice (37). Moreover, IL-6 is responsible for amelioration of local and systemic inflammation by stimulation of IL-10 production (38).

Previous experiments in mice overexpressing IL-6 gene in pancreatic beta cells add a confirmation for a possible protective role of IL-6 in the prediabetes stage. The transgenic nonobese diabetic (NOD) mice, which overexpressed human IL-6 in pancreatic beta cells, had lower average fasting glucose levels, a delayed onset of diabetes, and a longer survival compared with age and sex matched littermates without IL-6 gene overexpression (39). In another study, the high IL-6 production in IL-6 gene overexpressing mice seemed to be specifically protective in the prediabetes phase by stimulating islet cell hypertrophy with beta cell neogenesis suggestive of reparatory processes (40). Thus, it follows from our discussion that in the population of $-174 \mathrm{GG}$ young diabetic patients, the prediabetic insulitis may last longer due to IL-6-dependent amelioration of insulin deficiency.

It remains in the sphere of speculation as to how the -174GG genotype may shield against diabetic complications. Both retinopathy and nephropathy are associated with inflammatory conditions (41). Recently published articles have shed more light on this problem. Experiments have documented the neuroprotective role of IL-6, which may merit in the protection against diabetic retinopathy. IL-6 produced by glial cell cultures in vitro was able to save the retinal ganglion cells from apoptosis both in conditions of elevated pressure, which usually reduce retinal cell survival, and in the ischemicreperfusion injury $(42,43)$.

The literature that we came across disallows any conclusion about the protective mechanism of IL-6 against nephropathy. IL-6 blood level in our study was not elevated in the $-174 \mathrm{GG}$ genotype patients who in other pathologic circumstances were characterized as high IL-6 producers $(10-12,15,16)$. The above-mentioned circumstances were, however, associated with an acute inflammatory response while formation of the microvascular complications is due to chronic inflammation. Instead, we showed high IL-6 concentration in the urine of the -1744 GG patients, which was much probably produced locally $(44,45)$. It can be easily deduced that the high IL-6 concentration in urine was not a result of both filtration, and a subsequent renal reabsorption may easily be deduced. If IL-6 had been filtered, its urine levels would strongly decrease and that of the blood samples significantly increase (46). Meanwhile, we did not find an elevation of the blood IL-6 in the $-174 \mathrm{GG}$ group and just opposite the high IL-6 level was visible in urine of these patients. One of the IL-6 protective mechanisms may rely on stimulation of high IL-10 production, which we found in earlier clinical studies (47).

Summarizing, we found that the IL6 - 174GG homozygotes were under represented in the T1DM young patients, and they were free from retinopathy and nephropathy. We propose that the $-174 \mathrm{GG}$ patients are protected from late diabetic complications by different IL-6 dependent mechanisms.

\section{REFERENCES}

1. Schram MT, Chaturved N, Schalkwijk CG, Fuller JH, Stehouwer CD; EURODIAB Prospective Complications Study Group 2005 Markers of inflammation are cross- 
sectionally associated with microvascular complications and cardiovascular disease in type 1 diabetes - the EURODIAB Prospective Complications Study. Diabetologia 48:370-378

2. Fishman D, Faulds G, Jeffery R, Mohamed-Ali V, Yudkin JS, Humphries S, Woo P 1998 Effect of novel polymorphisms in the interleukin-6 (IL-6) gene on IL-6 transcription and plasma IL-6 levels, and an association with systemic-onset juvenile chronic arthritis. J Clin Invest 102:1369-1376

3. Rivera-Chavez FA, Peters-Hybki DL, Barber RC, O'Keefe GE 2003 Interleukin-6 promoter haplotypes and interleukin-6 cytokine responses. Shock 20:218-223

4. Bennermo M, Held C, Stemme S, Ericsson CG, Silveira A, Green F, Tornvall P 2004 Genetic predisposition of the interleukin-6 response to inflammation: implications for a variety of major diseases? Clin Chem 50:2136-2140

5. Rundek T, Elkind MS, Pittman J, Boden-Albala B, Martin S, Humphries SE, Juo SH, Sacco RL 2002 Carotid intima-media thickness is associated with allelic variants of stromelysin-1, interleukin-6, and heapatic lipase genes: the Northern Prospective Cohort Study. Stroke 33:1420-1423

6. Basso F, Lowe GD, Rumley A, McMahon AD, Humphries SE 2002 Interleukin-6-174 $\mathrm{G}>\mathrm{C}$ polymorphism and risk of coronary heart disease in West of Scotland coronary prevention study (WOSCOPS). Arterioscler Thromb Vasc Biol 22:599-604

7. Balding J, Livingstone WJ, Pittock SJ, Mynett-Johnson L, Ahern T, Hodgson A, Smith OP 2004 The IL-6 G-174C polymorphism may be associated with ischaemic stroke in patients without a history of hypertension. Ir J Med Sci 173:200-203

8. Pola R, Flex A, Gaetani E, Flore R, Serricchio M, Pola P 2003 Synergistic effect of $-174 \mathrm{G} / \mathrm{C}$ polymorphism of the interleukin- 6 gene promoter and $469 \mathrm{E} / \mathrm{K}$ polymorphism of the intercellular adhesion molecule-1 gene in Italian patients with history of ischemic stroke. Stroke 34:881-885

9. Myśliwska J, Więckiewicz J, Hak L, Siebert J, Rogowsk J, Szyndler K, Myśliwski A 2006 Interleukin 6 polymorphism corresponds to the number of severely stenosed coronary arteries. Eur Cytokine Netw 17:181-188

10. Burzotta F, Iacoviello L, Di Castelnuovo A, Glieca F, Luciani N, Zamparelli R, Schiavello R, Donati MB, Maseri A, Possati G, Andreotti F 2001 Relation of the -174 G/C polymorphism of interleukin-6 to interleukin-6 plasma levels and to length of hospitalization after surgical coronary revascularization. Am J Cardiol $88: 1125-1128$

11. Gaudino M, Di Castelnuovo A, Zamparelli R, Androetti F, Burzotta F, Iacoviello L, Glieca F, Alessandrini F, Nasso G, Donati MB, Maseri A, Schiavello R, Possati G 2003 Genetic control of postoperative systemic inflammatory reaction and pulmonary and renal complications after coronary artery bypass surgery. $\mathrm{J}$ Thorac Cardiovasc Surg 126:1107-1112

12. Gaudino M, Andreotti F, Zamparelli R, Di Castelnuovo A, Nasso G, Burzotta F, Iacoviello L, Donati MB, Schiavello R, Maseri A, Possati G 2003 The -174G/C interleukin-6 polymorphism influences postoperative interleukin-6 levels and postoperative atrial fibrillation. Is atrial fibrillation an inflammatory complication? Circulation 108:II195-II199

13. Myśliwska J, Więckiewicz J, Hak L, Siebert J, Rogowski J, Szyndler K, Myśliwski A 2007 Long-term prognosis after coronary bypass surgery depends on interleukin 6 polymorphism and past acute infections. Int J Cardiol 118:421-422

14. Antonicelli R, Olivieri F, Bonafè M, Cavallone L, Spazzafumo L, Marchegiani M, Cardelli M, Recanatini A, Testarmata P, Boemi M, Parati G, Franceschi F 2005 The interleukin-6-174 G $>$ C promoter polymorphism is associated with a higher risk of death after an acute coronary syndrome in male elderly patients. Int $\mathrm{J}$ Cardiol 103:266-271

15. Merino A, Gaya A, Segura I, Calvo J, Imizcoz C, Berenguel A, Alegria E 2004 Platelet aggregation inhibition blocks $\mathrm{C}$-reactive protein and interleukin-6 elevation after the coronary angioplasty: effect of the $-174 \mathrm{G} / \mathrm{C}$ IL6 gene polymorphism. Am J Cardiol 94:1300-1303

16. Trevelyan J, Brull DJ, Needham EW, Montgomery HE, Morris A, Mattu RK 2004 Effect of enalapril and losartan on cytokines in patients with stable angina pectoris awaiting coronary artery bypass grafting and their interaction with polymorphisms in the interleukin-6 gene. Am J Cardiol 94:564-569

17. Humphries SE, Luong LA, Ogg MS, Hawe E, Miller GJ 2001 The interleukin-6-174 $\mathrm{G} / \mathrm{C}$ promoter polymorphism is associated with risk of coronary heart disease and systolic blood pressure in healthy men. Eur Heart J 22:2243-2252

18. Bittar MN, Carey JA, Barnard J, Fildes JE, Pravica V, Yonan N, Hutchinson IV 2005 Interleukin $6 \mathrm{G}-174 \mathrm{C}$ polymorphism influences outcome following coronary revascularization surgery. Heart Surg Forum 8:E140-E145

19. Huth C, Illig T, Herder C, Gieger C, Grallert H, Vollmert C, Rathmann W, Hamid YH, Pedersen O, Hansen T, Thorand B, Meisinger C, Doring A, Klopp N, Gohlke H, Lieb W, Hengstenberg C, Lyssenko V, Groop L, Ireland H, Stephens JW, Wernstedt Asterholm I, Jansson JO, Boeing H, Mohlig M, Stringham HM, Boehnke M, Tuomilehto J, Fernandez-Real JM, Lopez-Bermejo A, Gallart L, Vendrell J, Humphries SE, Kronenberg F, Wichmann HE, Heid IM 2009 Joint analysis of individual participants' data from 17 studies on the association of the IL6 variant $-174 \mathrm{G}>\mathrm{C}$ with circulating glucose levels, interleukin-6 levels, and body mass index. Ann Med 41:128-138

20. Eerligh P, Koeleman BP, Dudbridge F, Jan Bruining G, Roep BO, Giphart MJ 2004 Functional genetic polymorphisms in cytokines and metabolic genes as additional genetic markers for susceptibility to develop type 1 diabetes. Genes Immun 5:36-40

21. Cooper JD, Smyth DJ, Bailey R, Payne F, Downes K, Godfrey LM, Masters J, Zeitels LR, Vella A, Walker NM, Todd JA 2007 The candidate genes TAF5L, TCF7, PDCD1, IL6 and ICAM1 cannot be excluded from having effects in type 1 diabetes. BMC Med Genet 8:71
22. Gillespie KM, Nolsoe R, Betin VM, Kristiansen OP, Bingley PJ, Madrup-Poulsen T, Gale E 2005 Is puberty an accelerator of type 1 diabetes in IL-6-174 CC females? Diabetes 54:1245-1248

23. Hermann C, Krikovszky D, Fust G, Kovacs M, Korner A, Szabo A, Vannay A, Madacsy L 2005 Association between interleukin-6 polymorphism and age-at-onset of type 1 diabetes epistatic influences of the tumor necrosis factor- $\alpha$ and interleukin-1 $\beta$ polymorphisms. Eur Cytokine Netw 16:277-281

24. Jahromi MM, Millward BA, Demaine AG 2000 A polymorphism in the promoter region of the gene for interleukin- 6 is associated with susceptibility to type 1 diabetes mellitus. J Interferon Cytokine Res 20:885-888

25. Rudofsky G Jr, Schlotterer A, Reismann P, Engel J, Grafe IA, Tafel J, Morcos M, Humpert PM, Nawroth P, Bierhaus A, Hamann A 2009 The $-174 \mathrm{G}>\mathrm{C}$ IL-6 gene promoter polymorphism and diabetic microvascular complications. Horm Metab Res 41:308-313

26. Genuth S, Alberti KG, Bennett P, Buse J, Defronzo R, Kahn R, Kitzmiller J, Knowler WC, Lebovitz H, Lernmark A, Nathan D, Palmer J, Rizza R, Saudek C, Shaw J, Steffes M, Stern M, Tuomilehto J, Zimmet P; Expert Committee on the Diagnosis and Classification of Diabetes Mellitus 2003 Follow-up report on the diagnosis of diabetes mellitus. Diabetes Care 26:3160-3167

27. 1991 Classification of diabetic retinopathy from fluorescein angiograms. ETDRS report number 11. Early Treatment Diabetic Retinopathy Study Research Group. Ophthalmology 98:807-822

28. Cockcroft DW, Gault MH 1976 Prediction of creatinine clearance from serum creatinine. Nephron 16:31-41

29. Andreozzi F, Laratta E, Cardellini M, Marini MA, Lauro R, Hribal ML, Perticone F, Sesti G 2006 Plasma interleukin-6 levels are independently associated with insulin secretion in a cohort of Italian-Caucasian nondiabetic subjects. Diabetes 55:2021-2024

30. Fernandez-Real JM, Vayreda M, Richart C, Gutierrez G, Broch M, Vendrell J, Ricart W 2001 Circulating interleukin-6 levels, blood pressure, and insulin sensitivity in apparently healthy men and women. J Clin Endocrinol Metab 86:1154-1159

31. Buschard K, Aaen K, Horn T, Van Damme J, Bendtzen K 1990 Interleukin-6 a functional and structural in vitro modulator of beta-cells from islets of Langerhans. Autoimmunity 5:185-194

32. Shimizu H, Ohtani K, Kato Y, Mori M 2000 Interleukin-6 increases insulin secretion and preproinsulin mRNA expression via $\mathrm{Ca}^{2+}$-dependent mechanism. J Endocrinol $166: 121-126$

33. Kim S, Kim HS, Chung KW, Oh SH, Yun JW, Im SH, Lee MK, Kim KW, Lee MS 2007 Essential role for signal transducer and activator of transcription-1 in pancreatic beta-cell death and autoimmune type 1 diabetes of non-obese diabetic mice. Diabetes 56:2561-2568

34. Suk K, Kim S, Kim YH, Kim KA, Chang I, Yagita H, Shong M, Lee MS 2001 IFN-gamma/TNF-alpha synergism as the final effector in autoimmune diabetes: a key role for STAT1/IFN regulatory factor-1 pathway in pancreatic beta cell death. J Immunol 166:4481-4489

35. Størling J, Binzer J, Andersson AK, Züllig RA, Tonnesen M, Lehmann R, Spinas GA, Sandler S, Billestrup N, Mandrup-Poulsen T 2005 Nitric oxide contributes to cytokine-induced apoptosis in pancreatic beta cells via potentiation of JNK activity and inhibition of Akt. Diabetologia 48:2039-2050

36. Tilg H, Trehu E, Atkins MB, Dinarello CA, Mier JW 1994 Interleukin-6 (IL-6) as an anti-inflammatory cytokine: induction of circulating IL-1 receptor antagonist and soluble tumor necrosis factor receptor p55. Blood 83:113-118

37. Wang JL, Qian X, Chinookoswong N, Lu J, Chow G, Theill LE, Shi ZQ 2002 Polyethylene glycolated recombinant TNF receptor I improves insulitis and reduces incidence of spontaneous and cyclophosphamide-accelerated diabetes in non-obese diabetic mice. Endocrinology 143:3490-3497

38. Xing Z, Gauldie J, Cox G, Baumann H, Jordana M, Lei XF, Achong MK 1998 IL-6 is an anti-inflammatory cytokine required for controlling local or systemic acute inflammatory responses. J Clin Invest 101:311-320

39. DiCosmo BF, Picarella D, Flavell RA 1994 Local production of human IL-6 promotes insulitis but retards the onset of insulin-dependent diabetes mellitus in non-obese diabetic mice. Int Immunol 6:1829-1837

40. Campbell IL, Hobbs MV, Dockter J, Oldstone MB, Allison J 1994 Islet inflammation and hyperplasia induced by the pancreatic islet-specific over expression of interleukin-6 in transgenic mice. Am J Pathol 145:157-166

41. Thomson SE, McLennan SV, Kirwan PD, Heffernan SJ, Hennessy A, Yue DK, Twigg SM 2008 Renal connective tissue growth factor correlates with glomerular basement membrane thickness and prospective albuminuria in a non-human primate model of diabetes: possible predictive marker for incipient diabetic nephropathy. J Diabetes Complications 22:284-294

42. Sappington RM, Chan M, Calkins DJ 2006 Interleukin-6 protects retinal ganglion cells from pressure-induced death. Invest Ophthalmol Vis Sci 47:2932-2942

43. Sanchez RN, Chan CK, Garg S, Kwong JM, Wong MJ, Sadun AA, Lam TT 2003 Interleukin-6 in retinal ischemia reperfusion injury in rats. Invest Ophthalmol Vis Sci 44:4006-4011

44. Grassl C, Luckow B, Schlöndorff D, Dendorfer U 1999 Transcriptional regulation of the interleukin-6 gene in mesangial cells. J Am Soc Nephrol 10:1466-1477

45. Granfeldt A, Ebdrup L, Tonnesen E, Wogensen L 2008 Renal cytokine profile in an endotoxemic porcine model. Acta Anaesthesiol Scand 52:614-620

46. Kudo S, Goto H 1999 Intrarenal handling of recombinant human interleukin-1alpha in rats: mechanism for proximal tubular protein reabsorption. J Interferon Cytokine Res 19:1161-1168

47. Myśliwska J, Zorena K, Semetkowska-Jurkiewicz E, Rachoń D, Suchanek H, Myśliwski A 2005 High levels of circulating interleukin-10 in diabetic nephropathy patients. Eur Cytokine Netw 16:117-122 